\title{
SV40 and p53 as team players in childhood lymphoproliferative disorders
}

\author{
SUSANNE HEINSOHN, ROSWITHA SCHOLZ and HARTMUT KABISCH \\ University Medical Centre Hamburg Eppendorf, Centre for Women's and Children's Health, \\ Clinic and Polyclinic for Paediatric Haematology and Oncology, Martinistr. 52, 20246 Hamburg, Germany
}

Received November 22, 2010; Accepted January 14, 2011

DOI: 10.3892/ijo.2011.967

\begin{abstract}
Simian virus 40 (SV40) is known to be potently oncogenic and can induce several types of tumours, such as lymphoma. p53 was discovered as a cellular partner of the SV40 large T-antigen, the oncoprotein of this virus. There have not been many studies on SV40 and p53 in lymphomas and the ones that exist, are controversial. A comparison of these two components in lymphoma has not been reported previously. We examined 91 lymphomas [60 B-cell non-Hodgkin's lymphomas (B-NHLs), 19 B-cell acute lymphoblastic leukemias (B-ALLs), 7 B-cell precursor acute lymphoblastic leukemias and $5 \mathrm{~T}$-cell acute lymphoblastic leukemias] for the presence of SV40. Overall, 40 samples from $12 \mathrm{~B}-\mathrm{NHL} / 19 \mathrm{~B}-\mathrm{ALL}$ patients were additionally investigated for p53 mutation in the hot-spot exons 5 to 8 . Overall, we found 62/91 lymphomas to be SV40-positive, among them 16/19 B-ALLs and 38/60 B-NHLs. SV40 was absent in 147 of the 149 blood control samples. We found 11 p53 mutations in 19 B-ALL patients: 5 in exon 5 (codons 132, 141, 143, 155 and 181), 4 in exon 7 (codons 236, 238 and 248), 2 in exon 8 (codon 273). In B-NHL patients we found p53-mutations in 9/12 samples: 6 of these in 3 lymph nodes (LNs). One LN harboured 3 different p53 mutations: Exon 5 (codon 132), exon 6 (codon 213) and exon 8 (codon 288). Another LN showed 2 different p53 mutations: Exon 6 (codon 213) and exon 8 (codon 285). Except for 1 nonsense mutation in an LN of a B-NHL patient, all 20 mutations were missense mutations, 2 were homozygous, both found in B-NHLsamples, and one of these (codon 175) is known to cause the global denaturation of p53. All occur in the DNA-binding domain of p53. All specimens showing a p53 mutation, were
\end{abstract}

Correspondence to: Dr Susanne Heinsohn, University Medical Centre Hamburg Eppendorf, Centre for Women's and Children's Health, Clinic and Polyclinic for Paediatric Haematology and Oncology, Martinistr. 52, 20246 Hamburg, Germany

E-mail: heinsohn@uke.uni-hamburg.de

Key words: Simian virus 40, childhood lymphoma, lymphoproliferative disorder, p53, B-cell acute lymphoblastic leukemia, non-Hodgkin's lymphoma, human polyomavirus, oncogenic virus, tumour suppressor gene
SV40-positive. p53 mutaions found in LNs of B-NHL patients harbour high SV40 copy numbers. Our data strongly support an important role for SV40, as well as a strong association of SV40 and p53 in childhood lympho-proliferative disorders.

\section{Introduction}

Lymphoma. Human malignant lymphomas encompass a wide spectrum of different lymphoproliferative disorders. Lymphoma is a transformation of either B or $\mathrm{T}$ cells or their subtypes. With about 210 new patients per year in Germany, lymphomas collectively rank third in frequency among childhood malignancies with a peak in incidence between 5-8 years of age, followed by a second larger peak in the mid-teens. B-cell lymphoma as well as B-cell acute lymphoblastic leukemia (B-ALL) are the most rapidly growing human cancers.

The most frequently recognized alterations are chromosomal translocations, deregulation of cytokine networks, immune suppression, activation of oncogene expression, and inactivation of tumour suppressor genes. Up to now, there have not been many studies on viral infections and lymphoma (1), as these infections are aetiologically involved in these diseases.

It is known that p53 mutation is an important mechanistic step in the formation of diffuse large B-cell lymphomas (2). p53 is frequently mutated in Burkitt's lymphoma cell lines (3) and an unusual p53 mutation was detected in Burkitt's lymphoma (4). A recent study reported p53 mutations in circulating free DNA in patients with non-Hodgkin's lymphoma (NHL) (5).

The pathogenesis of B-cell lymphomas is not yet well understood. An association between infectious agents and lymphoma development has been demonstrated for mucosaassociated lymphoid tissue (MALT) lymphomas of the stomach caused by Heliobacter pylori infection and persistent initial primary cutaneous B-cell lymphomas triggered by the Borrelia burgdorferi infection $(6,7)$. Besides bacteria, viruses of the retrovirus and herpes families are possible aetiological agents of human leukaemias and lymphomas, so is Ebstein-Barr virus associated with Burkitt's lymphoma and Hodgkin's lymphoma and a viral cause has been postulated to increase the risk of NHLs in general (8-10). The discovery of human herpes virus type 8 (HHV-8 or KSHV) has led to the identification of a rare and unusual group of virus-associated lymphoproliferative diseases (11). Viral agents may contribute to the development of lymphomas by driving lymphoid cell proliferation or by 
inducing chronic antigenic stimulation $(12,13)$. Individuals infected with the human immunodeficiency virus (HIV) are at great risk (60- to 200 -fold) of developing lymphoma, although here the mechanism of lymphomagenesis is indirect (14). Certain data suggest that hepatitis $\mathrm{C}$ virus infection is also associated with the increased incidence of lymphoma $(15,16)$, whereas data relating lymphoma to Simian virus 40 (SV40), a highly oncogenic virus, remain rare. Nevertheless, SV40 could be taken into consideration for a putative role in human lymphomagenesis, alone or in combination with additional events, such as p53 mutation.

SV40. SV40 is a monkey virus that has been recognized as a contaminant of early polio vaccines provided to millions of individuals in Europe and the USA during mass vaccination between 1955 and 1963 (17-19). The relevance of SV40 to human pathology was first reported in 1962 by Shein et al (20) who found that SV40 is able to infect and transform human and animal cells in vitro. This transforming activity mainly results from the interaction of the SV40 large-T-antigen with cellular proteins, one of which is p53 (21). In 1972 it was reported for the first time, that SV40 induces leukaemia and lymphoma in hamster cells when inoculated systemically (22). SV40 DNA oncogenecity is associated with the primary viral gene product, the large T-antigen (L-TAG), known to promote transformation by binding and inactivating tumour suppressor genes, such as p53 and pRb. Cells expressing L-TAG exhibit disrupted cell cycle progression, abnormal mitosis and aneuploidy.

Over the years, an increasing number of reports have suggested that SV40 causes specific tumour types, such as mesothelioma, brain and bone tumours. Few studies have shown the presence of SV40 in lymphomas (23-31), and with contradicting results. Three studies $(28,32,33)$ found about a 10,13 and $14 \%$ incidence of SV40 in NHL, respectively, while 2 other studies $(23,34)$ found a nearly identical higher incidence of SV40 in NHL (42 and 43\%, respectively). Follow-up studies have not supported these findings $(25,29,33,35-38)$. MacKenzie et al failed to detect SV40 in a series of 152 NHLs even by using a highly sensitive TaqMan assay for SV40 detection, the same sensitive assay used in our investigation (29). Capello et al similarly failed to detect consistent evidence of SV40 infection in 485 lymphoma specimens (36). Other investigators have detected SV40 genomes in an intermediate proportion of cases $(32,37)$. Using immunohistochemistry, Brousset et al did not detect evidence of SV40 L-TAG in any of the tumour cells of 232 NHL samples (39). In contrast, Vilchez et al detected SV40 L-TAG in 12/55 HIV-associated lymphomas, although the viral antigen was detected in some but not all the tumour cells in an individual case (40).

Most lymphoma studies based their detection of SV40 DNA on PCR, except that of MacKenzie et al (29). One study which found no association of SV40 in any subtype of lymphoma of Spanish origin used virus-like-particle-based enzyme immunoassay with antibodies to SV40 (25). The reasons for the discrepant findings are not clear. Technical factors, such as differences in assay sensitivity $(41,42)$ and the lack of specifity of large T-antibodies are possible explanations.

$p 53$. The p53 protein was identified in 1979 as a cellular protein that forms a complex with the L-TAG of the oncogenic virus, SV40 $(43,44)$. Since then, p53 has become conspicuous as a tumour suppressor and up to now the multifunctional p53 gene is the best studied gene involved in human cancer (45-49). It is located on chromosome 17 (short arm, 17p13), a region that is frequently deleted in human cancer. The alteration or inactivation of $\mathrm{p} 53$ by mutation, or by its interaction with oncogenic products of DNA tumour viruses, can lead to cancers, such as childhood tumours and lymphoblastic malignancies (50-54). Compared to other cancer types, haematological malignancies present a rather low incidence of genetic alterations in the p53 protein (10-20\%), although the prognosis of patients with a mutation in the p53 gene is worse than those expressing the wild-type p53 protein (55-57). Moreover, p53 mutations are predictors of poor survival in B-cell lymphomas as well of a high-risk group of patients diagnosised with follicular lymphoma (58-60).

p53 mutations are the most common genetic changes in human cancer. The cell cycle is composed of a series of steps which can be negatively regulated by various factors. The p53 protein is the chief among the negative regulators. The p53 protein represses cell cycle proliferation and angiogenesis, and stimulates apoptosis mainly by acting as a transcription factor that controls the expression of genes whose gene products are involved in these processes (61). p53 arrests cell cycle progression in the G1/S and G2 phases. G1/S phase arrest is obtained through the p53-mediated activation of the gene encoding the cyclin dependant kinase inhibitor p21. G2 arrest by $\mathrm{p} 53$ is less clear, but it may involve the effectors $\mathrm{p} 21$ (62). The idea that the cellular p53 protein may be involved in the process of oncogenesis arose by virtue of its stable association with two different viral oncogenetic proteins, one of them SV40 L-TAG (63-67). Therefore a cooperation between SV40 and p53 function can be discussed as a cooperation of p53 point mutations with activated ras oncogene, as has been done for colorectal carcinomas (68). A recent report reflects on the common mechanism of transformation by small DNA viruses, such as SV40, and the inactivation of p53 (69). Except for one report, correlating SV40 and p53 in diffuse large B-cell lymphoma in Tunesia (70), such a correlation has not been studied as far as we know for childhood lymphoproliferative disorders. That study looked for the accumulation of p53 in the nucleus, not for p53 mutations, specifically.

In this study, we aimed to determine the prevalence and what role SV40 could play in lymphomas alone or in correlation with p53. Moreover, we aimed to obtain more information regarding the role of p53 in virally-associated or -infected tumours. Therefore, we investigated 91 cases of childhood lymphoproliferative malignancies and 151 control cases. In addition to conventional PCR and sequencing, we used the highly sensitive real-time PCR for the identification of SV40 in patient specimens. Till now, the latter is not a wide-spread method for the detection and identification of SV40, although we found this technique to be very appropriate for detecting and identifying, as well as for the quantification of SV40 in one step.

Moreover, we addressed the question of whether SV40 positivity correlates with $\mathrm{p} 53$ mutation in lymphomas, especially in B-ALLs, as well in B-NHLs. To our knowledge, a similar study on lymphomas has not been done up to now. This raises some very important questions, as L-TAG has a p53 binding site and is known to block p53 functions. 


\section{Materials and methods}

Materials. Fresh or frozen samples from bone marrow (BM) or peripheral blood (PB) from 91 children with lymphoproliferative disorders [19 B-ALLs, 7 B-cell precursor acute lymphoblastic leukemias (BCP-ALLs), 5 T-cell acute lymphoblastic leukemias (T-ALLs) and 60 B-NHLs] obtained at the time of diagnosis, containing between 50 and $90 \%$ malignant cells, as well as 149 fresh buffy coats from healthy German subjects derived from the blood transfusion centre, were analysed. The human fibroblast cell line, SV80, with multiple extra chromosomal SV40 copies and the African green monkey kidney cell line, COS-7, with one integrated SV40 copy, served as the positive controls. DNA derived from SV40-negative healthy subjects as well as DNA derived from normal bone served as the negative controls.

Isolation of viral and chromosomal DNA. Genomic DNA was extracted from fresh or frozen cells using Qiagen spin columns (QIAamp DNA mini or midi kit; Qiagen, Hilden, Germany) following the 'blood and body fluid protocol', according to the recommendations of the supplier. This DNA extraction method is suitable for extracting chromosomal, as well as extrachromosomal, episomal DNA $(71,72)$.

SV4O-specific PCR. SV40-specific primers were adapted to the L-TAG region, previously proven to be very specific (33,73): SV5 (5'-TAG ATT CCA ACC TAT GGA ACT GA-3', nt 4574-4552) and SV6 (5'-GGA AAG TCC TTG GGG TCT TCT ACC-3', nt 4402-4425) (73) (Fig. 1). The amplification product is a $172 \mathrm{bp}$ fragment, including the retinoblastoma ( $\mathrm{Rb}$ ) pocket-binding domain with no intron sequences of L-TAG. DNA polymerase reaction was carried out using the 'Promega-Core-Kit' with TagBead Hot Start polymerase in the presence of $2.5 \mathrm{mM} \mathrm{MgCl}_{2}$ and $0.5 \mu \mathrm{M}$ of each primer in a final volume of $100 \mu \mathrm{l}$. PCR reactions were performed as previously described (74) with an annealing temperature of $56^{\circ} \mathrm{C}$ and 45 cycles. Amplification fragments were analysed on agarose gel electrophoresis, with ethidium bromide staining. SV40-positive fragments were cut out, purified, and verified by sequencing and real-time PCR , including one hybridization step simultaneously.

Real-time quantitative PCR (RQ-PCR) for SV40. All amplification primers were selected for the $\mathrm{Rb}$ pocket-binding domain of SV40 L-TAG. For RQ-PCR, forward primer $\left(\mathrm{F}^{+}\right)$ 5'-GGGTCTTCTACCTTTCTCTTCTTT-3' (nt 4414-4437) and reverse primer (A) 5'-GCAGTGGTGGAATGCCTTT-3'

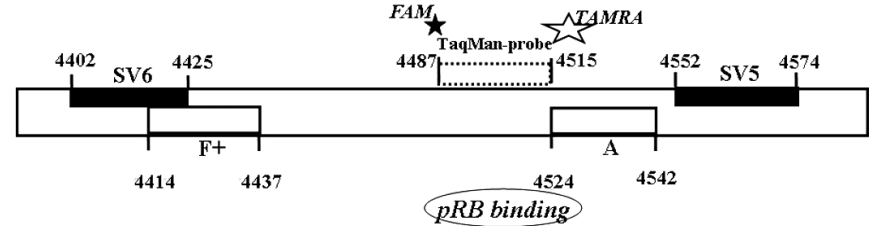

Figure 1. SV40 L-TAG specific primers and binding domain. Schematic diagram of SV40-TAG and the position of primers and probes used in this study (top). At the bottom schematic diagram of the corresponding amplification products (172 bp for SV5/6 and $128 \mathrm{bp}$ for $\mathrm{F}^{+} / \mathrm{A}^{-}$primers) the positions of the RB pocket-binding domain are indicated.

(nt 4524-4542) with the internal TaqMan probe (TM-probe) 5'-AACCTGTTTTGCTCAGAAGAAATGCCA-3' (nt 44874514) labelled with FAM (6-carboxyfluorescin) at the $5^{\prime}$ end and TAMRA (6-carboxytetramethylrhodamine) at the $3^{\prime}$ end (TIB Molbiol, Berlin, Germany), were used. For conventional PCR, primers SV5 and SV6, previously described in detail, were used (74) (Fig. 1).

The quality of the DNA was tested by amplification of the $\beta$-globin gene. Only samples with $C_{T}$ values of $20 \pm 1$ cycle were selected for quantification. RQ-PCR reaction was carried out as described previously with an annealing temperature of $60^{\circ} \mathrm{C}$ (41). SV40-positive cell line (COS-1) DNA was serial diluted in SV40-negative DNA to achieve equal amounts in each dilution sample (500 ng per reaction). RQ-PCR reactions were performed with 6 dilutions $\left(10^{-1}\right.$ to $\left.10^{-6}\right)$, an unrelated SV40-negative DNA control, a negative control and the sample of interest in triple. Selected samples were analysed by agarose gel electrophoresis, cut out and finally sequenced.

p53 mutation analysis. p53 was screened for mutations in exon 5-8, the regions, harbouring somatic hot-spot mutations $(75,76)$. In these sequences, encompassing exons 5 through 8 , most of the evolutionarily conserved amino acids are concentrated. Therefore, mutation analysis has been confined principally to these exons. Mutations outside this region are rare. Forward and reverse sequencing was carried out for all samples. In the case of a mutation, this was verified by a second independent reaction.

Primer sequences were adapted from the ones described by Weyrer et al (77) and are summarized in Table I. PCR reaction was carried out according the protocol of Sturm et al (78), with an initial denaturation at $94^{\circ} \mathrm{C}$ for $5 \mathrm{~min}$ and a final extension of $7 \mathrm{~min}$ at $72^{\circ} \mathrm{C}$ each. Annealing temperatures were $55^{\circ} \mathrm{C}$ for exon $5 \mathrm{a}, 65^{\circ} \mathrm{C}$ for exon $5 \mathrm{~b}, 60^{\circ} \mathrm{C}$ for exon 6 and 8 , and $58^{\circ} \mathrm{C}$ for exon 7 with a 20 -sec annealing time for each.

Table I. PCR primers used for p53 mutation analysis.

\begin{tabular}{llll}
\hline Exon & \multicolumn{1}{c}{ Sense-primer } & Antisense-primer & Codon \\
\hline 5a & 5'-CCA GTT GCT TTA TCT GTT CA-3' & 5'-TGT GGA ATC AAC CCA CAG-3' & $126-150$ \\
5b & 5'-CAA CTG GCC AAG ACC TGC-3' & 5'-AAC CAG CCC TGT CGT CTC T-3' & $151-186$ \\
6 & 5'-CTC TGA TTC CTC ACT GAT TGC-3' & 5'-GAG ACC CCA GTT GCA AAC CA-3' & $187-224$ \\
7 & 5'-TTG CCA CAG GTC TCC CCA A-3' & 5'-AGG GTG GCA AGT GGC TCC-3' & $225-261$ \\
8 & 5'-CCT TAC TGC CTC TTG CTT C-3' & 5'-CGC TTC TTG TCC TGC TTG C-3' & $262-306$ \\
\hline
\end{tabular}




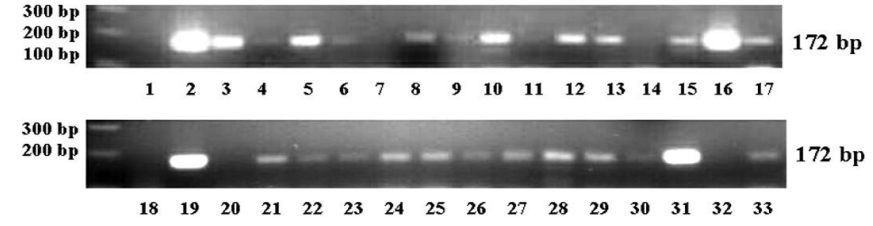

Figure 2. SV40 PCR products in B-cell lymphoma using the primers SV5/SV6, visualized on a $2 \%$ agarose gel, and stained with ethidium bromide. Lanes 2, 19 (SV80), 16 and 31 (COS-7) represent the SV40-positive control cell lines. Lanes 1 and 18 are water as the negative PCR control. All other lanes represent DNA derived from B-cell lymphoma patients. Lanes 4 (PBL), 5 (BM), 24 (diagnosis) and 25 (end of therapy) each represent the same patient. Patients in lanes 7, 11, 14, 20 and 32 are SV40-negative. All positive signals were verified by direct sequencing as well as by RQ-PCR.

The reaction mixture contained $100 \mu \mathrm{mol} / \mathrm{l}$ of each primer, $1 \mathrm{mmol} / 1 \mathrm{MgCl}_{2}$ (except for exon 7: $0,8 \mathrm{mmol} / 1 \mathrm{MgCl}_{2}$ ), $1,5 \mathrm{U}$ TaqDNA polymerase (Platinum Taq, Invitrogen) in a total volume of $50 \mu 1$. PCR fragments were analysed on agarose gel electrophoresis, with ethidium bromide staining, cut out, purified, and finally sequenced.

Sequencing. The SV40 and p53 PCR products were cut out of the agarose gel, purified and extracted on 'Ultrafree-DA' spin columns (Millipore, Eschborn, Germany) at $5000 \mathrm{x} \mathrm{g}$ for 10 min. Purified DNA $(2 \mu \mathrm{l})$ was used to produce singlestranded marked DNA, necessary for sequencing (ABI PRISM BigDye Terminator Cycle Sequencing Ready Reaction Kit), with both the forward and reverse primers previously used for amplification. The cycle sequencing reaction was: A $95^{\circ} \mathrm{C}$ denaturation for $30 \mathrm{sec}, 30 \mathrm{sec}$ annealing with the temperature announced previously for the selected primers, and a $60^{\circ} \mathrm{C}$ elongation for $4 \mathrm{~min}$, in a total of 35 cycles. Products were sequenced on the 3130-Genetic Analyser (Applied Biosystems). Sequence data were first analysed by visual inspection and then with SeqMan Pro (DNAstar Lasergene-8) for mutations and compared to reference sequences. 553 mutations found in patients were compared to the UMD p53 website (79) for certification.

\section{Results}

The aim of this study was to investigate whether SV40 is present in lymphoproliferative disorders in German children as well as to determine the spread of SV40 in normal German subjects. Moreover, we wanted to determine the mutation rate of p53 at the well-known hot-spot regions exons 5 to 8 and to correlate this with the prevalence of SV40 in lymphoma specimens to get a hint of whether SV40 and p53 are co-players in this malignancy.

SV40 analysis. Overall, we analysed 91 BM samples at the time of diagnosis from childhood lymphoproliferative disorders (19 B-ALLs, 7 BCP-ALLs, 5 T-ALLs and 60 B-NHLs) for the presence of SV40. Samples from the 19 B-ALL patients were initially analysed by conventional PCR (Fig. 2) and in a
A

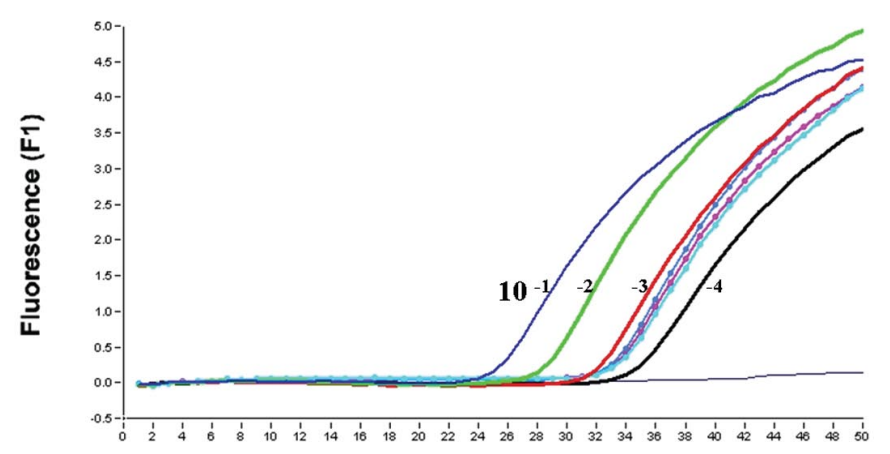

Cycle Number

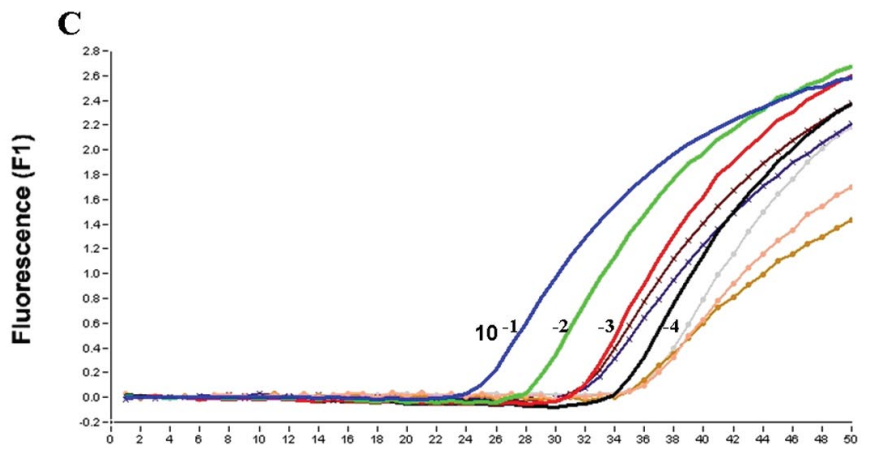

Cycle Number
B

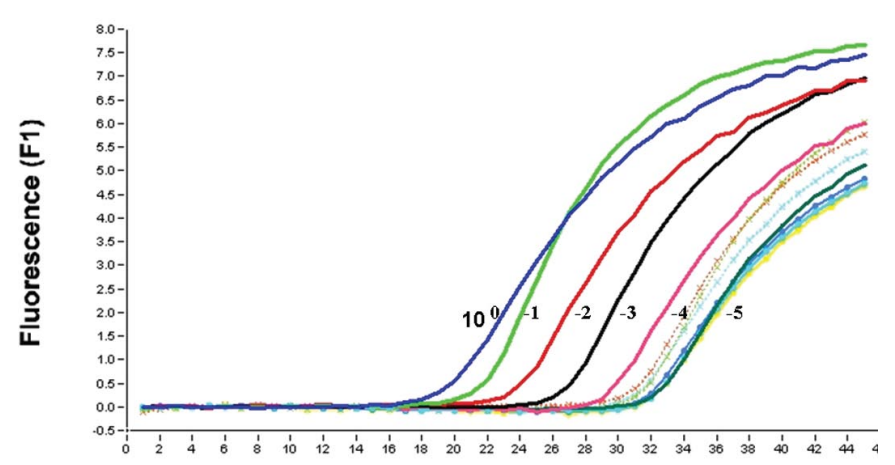

Cycle Number

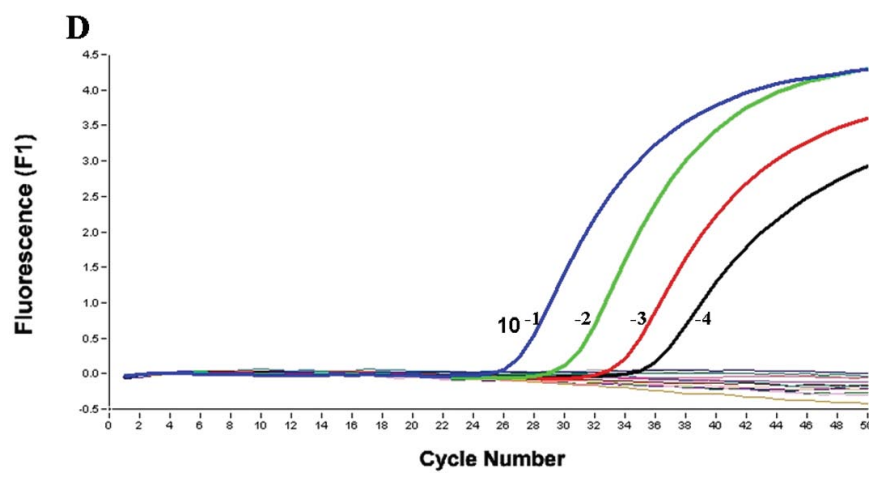

Figure 3: Detection of SV40-TAG sequences in lymphomas by RQ-PCR. In each image (A-D) the standard curve, derived from a 10-fold dilution (down to $4 \mathrm{log}$ ) of the control cell line, COS-1 (having one integrated single copy of SV40), is indicated. (A) BM sample of a B-ALL patient, tested in triplicate (dotted lines). (B) BM of 2 B-NHL patients (dotted and crossed lines), each tested in triplicate. (C) BM of 1 C-ALL- (dotted lines) and 1 B-ALL-patient (crossed lines), each tested in duplicate. (D) SV40 in PB of healthy volunteers, all tested negative. All positive samples were verified by direct sequencing. 
Table II. Results for SV40 and p53 analysis.

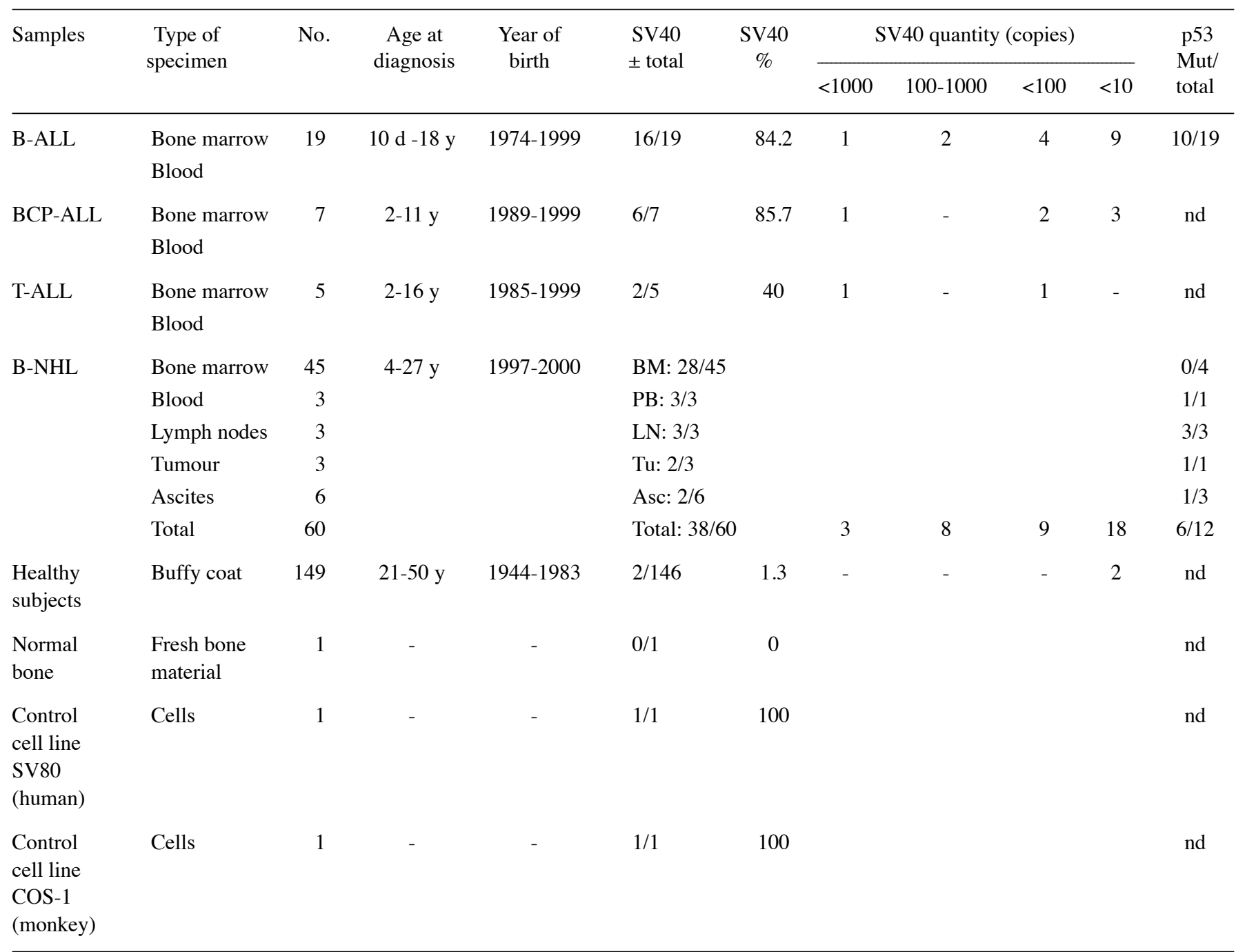

Mut, mutation; d, days; y, years.

second analysis round by RQ-PCR. Data derived from SV40 analysis with conventional PCR with SV5/SV6-primers showed that 5 out of 19 B-ALL patients were SV40-negative, while 2 of these negative patients were SV40-positive in the second additional SV40 analysis with the more sensitive RQ-PCR method. At least 16 out of the 19 B-ALL patients showed SV40 positivity. From 9 B-ALL patients we analysed more than one sample: In addition to BM, PB at the time of diagnosis or BM after chemotherapy in clinical remission, were analysed for SV40. These PB samples were SV40negative, while the corresponding BMs were positive. All BM samples taken after chemotherapy remained SV40-positive in the cases where the BM at the time of diagnosis was SV40positive.

All lymphoma samples were analysed by RQ-PCR. Overall, we found that 62/91 lymphoma patients were SV40-positive, and among these 16/19 B-ALLs, 6/7 BCP-ALLs, 2/5 T-ALLs and 38/60 B-NHLs. These $38 \mathrm{~B}-\mathrm{NHL}$ patients harboured SV40 in 3/3 PB, 3/3 lymph nodes (LNs), 2/3 tumours and 2/6 ascite (Asc) samples. From 5 B-NHL patients we analysed different samples at the time of diagnosis as well as during the course of the disease. Samples inlcuded LNs, Ascs, BM and
PB. From these 5 B-NHL patients all samples taken at the time of diagnosis (LN, BM and Asc) were SV40-positive, and in the case of LN, had a high SV40 copy number (100-1000 copies/500 ng DNA). Except for the Asc samples of 2 patients, all samples taken during the course of the disease of these 5 B-NHL patients, were SV40-positive.

Half of all the SV40-positive specimens from the 91 lymphomas analysed, harboured about $\leq 10$ copies SV40 in 500 ng DNA. Sixteen SV40-positive specimens showed 100 to $>1000$ SV40 copies in $500 \mathrm{ng}$ DNA. As the controls, we analysed 149 buffy coat samples from healthy blood donors. In the healthy population we found that only 2 out of 149 buffy coat samples were SV40-positive with $<10$ copies per 500 ng DNA. Examples are shown in Fig. 3A-D and all SV40 data are summarized in Table II.

p53 mutation analysis. Overall, 28 samples derived from the 19 B-ALL patients, from BM samples as well as from blood at the time of diagnosis, were subjected to SV40 analysis and screened for p53 mutations. Overall, we found 11 p53 mutations in these B-ALL specimens: 5 in exon 5 (codons 132, 141, 143, 155 and 181), 4 in exon 7 [codon 236s (2x), 238 and 248], 2 in 


\section{A: p53 mutations in B-ALL patients}

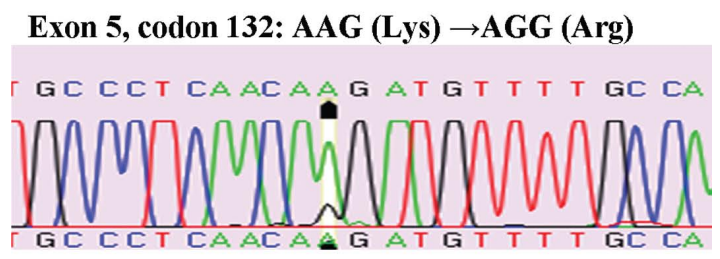

Exon 5, codon 141: TGC (Cys) $\rightarrow$ CGC (Arg) GGC CAAGACCTGCCCTGTGCA,

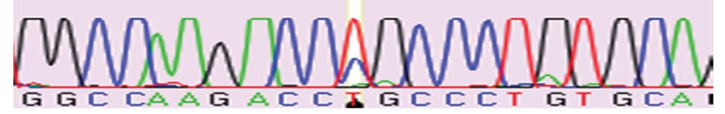

Exon 7, codon 236:

GTA (rev TAC, Tyr) $\rightarrow$ GGA (rev TCC, Ser)

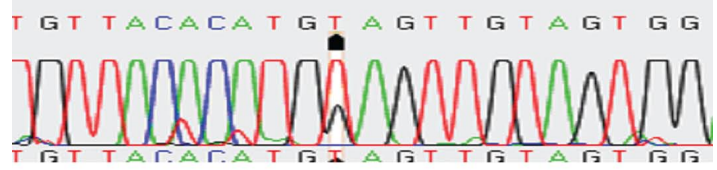

Exon 7, codon 248: CGG (Arg) $\rightarrow$ TGG (Trp)

$G G C G G C A T G A A C N G G A G G C D C A T \subset C$

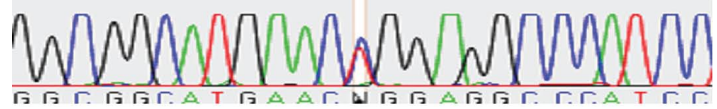

Exon 8, codon 273: CGT (Arg) $\rightarrow$ TGT (Cys)

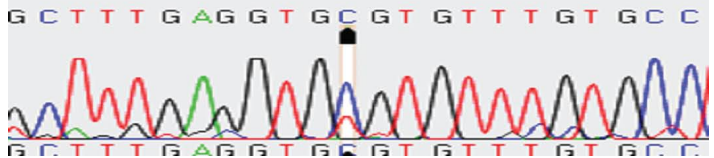

\section{B: p53 mutations in B-NHL patient 3}

\section{Exon 5, codon 176: TGC (Cys) $\rightarrow$ CGC (Arg)}

Ascites, homozygous

T GT GA GGC GC CGC C C C A C CAT

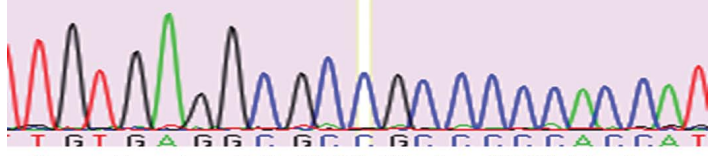

Exon 5, codon 176: TGC (Cys) $\rightarrow$ CGC (Arg)

PBL, heterozygous

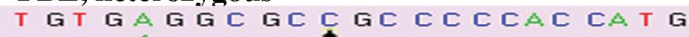

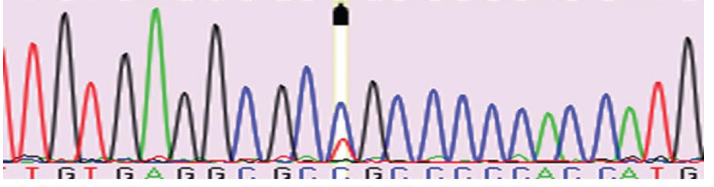

Exon 5, codon 176: TGC (Cys) wild type

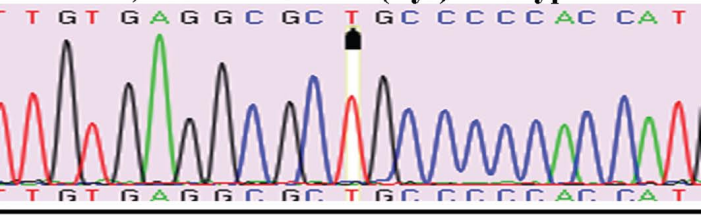

4C: $p 53$ mutations in B-NHL patient 4

Exon 5, codon 132: AAG (Lys) $\rightarrow$ ACG (Tyr)

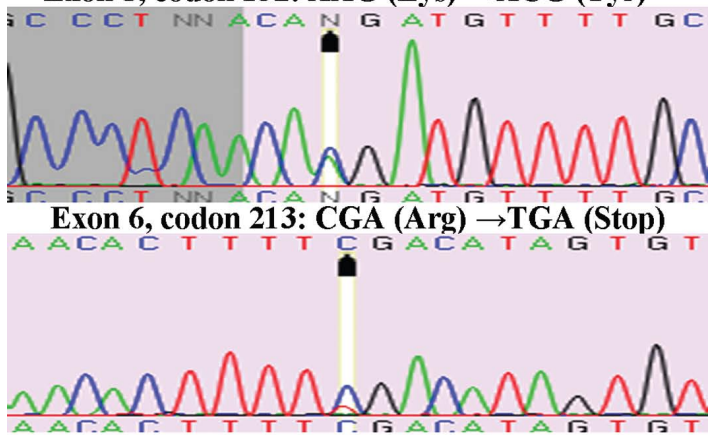

Figure 4: Examples of DNA sequences at the point of mutation in exons 5, 7 and 8 in the p53 gene. Mutations are indicated by arrows. (A) p53 mutations in samples of B-ALL patients. (B) p53 mutations in samples of B-ALL patient 3. (C) p53 mutations in the LN of B-NHL patient 4. Lys, lysine; Arg, arginine; Trp, tryptophan; Cys, cysteine; Ser, serine; Tyr, tyrosine.

exon 8 [codon $273(2 x)$ ], and none in exon 6. Examples are shown in Fig. 4 and summarized in Table III. The location of the full-length p53 gene is shown in Fig. 5.

Additionally, 12 different samples derived from 5 B-NHL patients were investigated for p53 mutation analysis. We chose those B-NHL patients from which we had LN samples, or those from which we had taken more than one sample during the course of disease. In 12 B-NHL samples we found 9 p53 mutations, 6 of these in 3 LNs. One LN (patient 4) harboured 3 different p53 mutations at the same time in exon 5 (codon 132), exon 6 (codon 213), and exon 8 (codon 288). Another LN (patient 1) showed 2 different p53 mutations at the same time in exon 6 (codon 213), and exon 8 (codon 285). One LN of B-NHL patient 2 showed one mutation in exon 5 (codon 175). This was a homozygous mutation which is known to cause the global denaturation of p53. A second homozygous p53 mutation (exon 5, codon 176) was found in an Asc sample at the time of diagnosis in patient 3 . The data of p53 mutations found in B-NHL patients are summarized in Table IV.

Overall, we found 20 p53 mutations in B-NHL/(B-ALL samples. All of these nucleotide changes detected, resulted in amino acid changes. Except for one nonsense mutation (exon 6, codon 213) in the LN of B-NHL patient 4, all 20 mutations found were missense mutations. Two p53 mutations were homozygous, both found in B-NHL-samples, and one of these patients harboured a germ line mutation. The mutations in codons 132, 141, 143, 155, 175, 181, 236, 238, 248 and 273 found in this investigation are all located in the DNA-binding domain of p53 (Fig. 5). The mutations in codons 175 and 273 and the Arg-248 mutation are known to be 'contact mutations', removing essential DNA-contact residues in the DNA-binding domain of p53, resulting in substantially impaired DNA-binding in addition to stability loss. The mutation in exon 5, codon 175 , found as a homozygous mutation in the LN of B-NHL patient 2, is described to cause the global denaturation of p53. For B-ALL patients, blood samples as well as BM samples taken after chemotherapy showed in each case a p53 wild-type constellation. Examples are shown in Fig. 4, and summarized in Table III for B-ALL and in Table IV for B-NHL patients. Overall, we found the well-known $\mathrm{C}$ to $\mathrm{T}$ transition in codon 248 of exon 7, in 4 out of 11 p53 mutations in B-ALL as well as in 1 out of 9 p53 mutations in B-NHL patients. 
Table III. p53 mutation analysis in B-ALL.

\begin{tabular}{|c|c|c|c|c|c|c|c|c|c|c|}
\hline $\begin{array}{l}\text { Sample no. } \\
\text { of B-ALL }\end{array}$ & Specimen & $\begin{array}{l}\text { Content of } \\
\text { vital tumour } \\
\text { cells }(\%)\end{array}$ & SV40 & Mutation & $\begin{array}{c}\text { Mutated } \\
\text { exon }\end{array}$ & $\begin{array}{l}\text { Mutated } \\
\text { codon }\end{array}$ & $\begin{array}{l}\text { Nucleotide } \\
\text { location }\end{array}$ & $\begin{array}{c}\text { Amino acid } \\
\text { change } \\
\mathrm{WT} \rightarrow \mathrm{Mut}\end{array}$ & $\begin{array}{l}\text { Sequence } \\
\text { change } \\
\text { WT } \rightarrow \text { Mut }\end{array}$ & $\begin{array}{l}\text { Nucleotide } \\
\text { change }\end{array}$ \\
\hline 1 & $\begin{array}{l}\text { BM-d } \\
\text { PBL }\end{array}$ & $\begin{array}{l}78 \\
85\end{array}$ & $\begin{array}{l}\text { Pos } \\
\text { Neg }\end{array}$ & $\begin{array}{l}\text { WT } \\
\text { WT }\end{array}$ & - & - & & - & - & - \\
\hline 2 & $\begin{array}{l}\text { BM-d } \\
\text { BM-th }\end{array}$ & 68 & $\begin{array}{l}\text { Pos } \\
\text { Pos }\end{array}$ & $\begin{array}{l}\text { Mut } \\
\text { WT }\end{array}$ & 5 & 143 & 13107 & Val $\rightarrow$ Glut & $\mathrm{GTG} \rightarrow \mathrm{GAG}$ & $\mathrm{T} \rightarrow \mathrm{A}$ \\
\hline 3 & $\begin{array}{l}\text { BM-d } \\
\text { BM-th }\end{array}$ & 54 & $\begin{array}{l}\text { Pos } \\
\text { Pos }\end{array}$ & $\begin{array}{l}\text { Mut } \\
\text { WT }\end{array}$ & 8 & 273 & 14485 & $\operatorname{Arg} \rightarrow$ Cys & $\mathrm{CGT} \rightarrow \mathrm{TGT}$ & $\mathrm{C} \rightarrow \mathrm{T}$ \\
\hline 4 & $\begin{array}{l}\text { BM-d } \\
\text { BM-th }\end{array}$ & 60 & $\begin{array}{l}\text { Pos } \\
\text { Pos }\end{array}$ & $\begin{array}{l}\text { Mut } \\
\text { WT }\end{array}$ & 5 & 155 & 13142 & $\mathrm{Thr} \rightarrow \mathrm{Ser}$ & $\mathrm{ACC} \rightarrow \mathrm{CC}$ & $\mathrm{A} \rightarrow \mathrm{T}$ \\
\hline 5 & $\begin{array}{l}\text { BM-d } \\
\text { BM-th }\end{array}$ & 80 & $\begin{array}{l}\text { Pos } \\
\text { Pos }\end{array}$ & $\begin{array}{l}\text { Mut } \\
\text { WT }\end{array}$ & 5 & 181 & 13220 & Arg $\rightarrow$ Cys & $\mathrm{CGC} \rightarrow \mathrm{TGC}$ & $\mathrm{C} \rightarrow \mathrm{T}$ \\
\hline 6 & $\begin{array}{l}\text { BM-d } \\
\text { BM-th }\end{array}$ & 60 & $\begin{array}{l}\text { Pos } \\
\text { Pos }\end{array}$ & $\begin{array}{l}\text { WT } \\
\text { WT }\end{array}$ & - & - & & - & - & - \\
\hline 7 & $\begin{array}{l}\text { BM-d } \\
\text { PBL }\end{array}$ & 50 & $\begin{array}{l}\text { Pos } \\
\text { Neg }\end{array}$ & $\begin{array}{l}\text { Mut } \\
\text { Mut }\end{array}$ & $\begin{array}{l}7 \\
7\end{array}$ & $\begin{array}{l}236 \\
236\end{array}$ & $\begin{array}{l}14034 \\
14034\end{array}$ & $\begin{array}{l}\text { Tyr } \rightarrow \text { Ser } \\
\text { Tyr } \rightarrow \text { Ser }\end{array}$ & $\begin{array}{l}\text { TAC } \rightarrow \text { TCC } \\
\text { TAC } \rightarrow \text { TCC }\end{array}$ & $\begin{array}{l}\mathrm{A} \rightarrow \mathrm{C} \\
\mathrm{A} \rightarrow \mathrm{C}\end{array}$ \\
\hline 8 & $\begin{array}{l}\text { BM-d } \\
\text { BM-th }\end{array}$ & 50 & $\begin{array}{l}\text { Pos } \\
\text { Pos }\end{array}$ & $\begin{array}{l}\text { WT } \\
\text { WT }\end{array}$ & - & - & & - & - & - \\
\hline 9 & BM-d & 50 & Pos & WT & - & - & & - & - & - \\
\hline 10 & BM-d & 70 & Pos & Mut & 7 & 238 & 14041 & Cys $\rightarrow$ Trp & $\mathrm{TGT} \rightarrow \mathrm{TGG}$ & $\mathrm{T} \rightarrow \mathrm{G}$ \\
\hline 11 & $\begin{array}{l}\text { BM-d } \\
\text { BM-th }\end{array}$ & 90 & $\begin{array}{l}\text { Pos } \\
\text { Pos }\end{array}$ & $\begin{array}{l}\text { WT } \\
\text { WT }\end{array}$ & - & - & & - & - & - \\
\hline 12 & BM-d & 50 & Pos & Mut & 5 & 141 & 13100 & Cys $\rightarrow$ Arg & $\mathrm{TGC} \rightarrow \mathrm{CGC}$ & $\mathrm{T} \rightarrow \mathrm{C}$ \\
\hline 13 & BM-d & 56 & Pos & Mut & 8 & 273 & 14485 & $\operatorname{Arg} \rightarrow$ Cys & $\mathrm{CGT} \rightarrow \mathrm{TGT}$ & $\mathrm{C} \rightarrow \mathrm{T}$ \\
\hline 14 & BM-d & 65 & Neg & WT & - & - & & - & - & - \\
\hline 15 & BM-d & 50 & Pos & Mut & 5 & 132 & 13074 & Lys $\rightarrow$ Arg & $\mathrm{AAG} \rightarrow \mathrm{AGG}$ & $\mathrm{A} \rightarrow \mathrm{G}$ \\
\hline 16 & BM-d & 70 & Neg & WT & - & - & & - & - & - \\
\hline 17 & BM-d & 75 & Pos & Mut & 7 & 248 & 14069 & $\operatorname{Arg} \rightarrow \operatorname{Trp}$ & $\mathrm{CGG} \rightarrow \mathrm{TGG}$ & $\mathrm{C} \rightarrow \mathrm{T}$ \\
\hline $18(\mathrm{Bt})$ & BM-d & 50 & $\mathrm{Neg}$ & WT & - & - & & - & & \\
\hline 19 & BM-d & 50 & Pos & WT & - & - & & - & & \\
\hline
\end{tabular}

Bt, Burkitt's type; BM-d, bone marrow at time of diagnosis; BM-th, bone marrow after chemotherapy; PBL, peripheral blood; WT, wild-type; Mut, mutation; Pos, positive; Neg, negative; Val, valine; Glut, glutamine; Arg, arginine; Cys, cysteine; Thr, threonine; Lys, lysine; Trp, tryptophan.

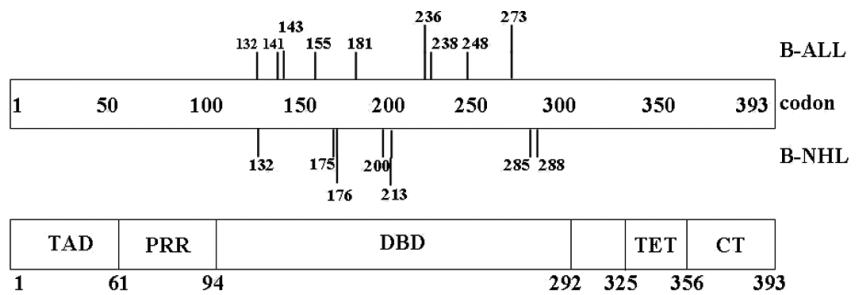

Figure 5. Domain structure of the full-length p53 gene (lower section) and location of the mutations found in this study (upper section). Codon numbers are indicated in both parts of the figure. Mutations in codons 176, 213, 236 and 273 were found twice. TAD, transactivation domain; PRR, prolin-rich region; DBD, central DNA-binding domain; TET, tetramerization domain; CT, C-terminus.

For one B-NHL patient we analysed Asc samples at the time of diagnosis as well as after relapse. While at the time of diagnosis the Asc sample was SV40-positive (100-1000 copies/500 ng DNA) and showed a homozygous p53 mutation in exon 5, the Asc sample at the time of relapse lost SV40 positivity as well as the p53 mutation. For this patient we analysed BM at the time of diagnosis and at the time of relapse as well as blood at the time of relapse. Both BM samples were SV40-positive (<100 copies/500 ng DNA) and showed wild-type p53, while the blood sample had more SV40 copies of 100-1000/500 ng DNA and had the same p53 mutation as was detected in the Asc sample at the time of diagnosis (exon 5, codon 176), although this was now heterozygous, not homozygous (Table IV).

All specimens having a p53 mutation were SV40-positive. Therefore, our results show a significant association between SV40 positivity and p53 mutation in B-NHL/B-All samples at the time of diagnosis.

\section{Discussion}

The central role of p53 in human cancer has been exhaustively discussed and reviewed over the years. Mutations in the p53 gene correlate with cancer ethiology and molecular patho- 
Table IV. p53 mutation analysis in B-NHL.

\begin{tabular}{|c|c|c|c|c|c|c|c|c|c|c|c|}
\hline Pat & Specimen & $\begin{array}{l}\text { Content of } \\
\text { vital tumour } \\
\text { cells }(\%)\end{array}$ & $\begin{array}{l}\text { SV40 } \\
\text { copies }\end{array}$ & Mutation & Exon & Codon & $\begin{array}{l}\text { Effect } \\
\text { type }\end{array}$ & $\begin{array}{l}\text { Nucleotide } \\
\text { location }\end{array}$ & $\begin{array}{l}\text { Amino acid } \\
\text { change }\end{array}$ & $\begin{array}{l}\text { Sequence } \\
\text { change }\end{array}$ & $\begin{array}{l}\text { Nulceotide } \\
\text { change }\end{array}$ \\
\hline \multirow[t]{2}{*}{1} & LN-d & 71 & $100-1000$ & Mut & 6 & 213 & Missense & 13398 & Arg $\rightarrow$ Leu & $\mathrm{CGA} \rightarrow \mathrm{CTA}$ & $\mathrm{G} \rightarrow \mathrm{T}$ \\
\hline & LN-d & & $100-1000$ & Mut & 8 & 285 & Missense & 14524 & $\mathrm{Glu} \rightarrow \mathrm{Asp}$ & $\mathrm{GAG} \rightarrow \mathrm{GAT}$ & $\mathrm{G} \rightarrow \mathrm{T}$ \\
\hline 2 & LN-d & 98 & $100-1000$ & Mut & 5 & 175 & $\begin{array}{c}\text { Missense } \\
\text { Homozygote }\end{array}$ & 13203 & Arg $\rightarrow$ His & $\mathrm{CGC} \rightarrow \mathrm{CAC}$ & $\mathrm{G} \rightarrow \mathrm{A}$ \\
\hline \multirow[t]{5}{*}{3} & Acs-d & nd & $100-1000$ & Mut & 5 & 176 & $\begin{array}{c}\text { Missense/ } \\
\text { homozygote }\end{array}$ & 13205 & Cys $\rightarrow$ Arg & $\mathrm{TGC} \rightarrow \mathrm{CGC}$ & $\mathrm{T} \rightarrow \mathrm{C}$ \\
\hline & BM-d & nd & $<100$ & WT & - & - & & - & - & - & - \\
\hline & $\mathrm{BM}-\mathrm{r}$ & 23 & $<100$ & WT & - & - & & - & - & - & - \\
\hline & Asc- $\mathrm{r}^{\mathrm{a}}$ & 80 & $\mathrm{Neg}$ & WT & - & - & & - & - & - & - \\
\hline & PBL-r & 36 & $100-1000$ & Mut & 5 & 176 & $\begin{array}{c}\text { Missense/ } \\
\text { heterozygote }\end{array}$ & 13205 & Cys $\rightarrow$ Arg & $\mathrm{TGC} \rightarrow \mathrm{CGC}$ & $\mathrm{T} \rightarrow \mathrm{C}$ \\
\hline \multirow[t]{4}{*}{4} & BM-d & nd & $<100$ & WT & - & - & & - & - & - & - \\
\hline & LN-d & 93 & $100-1000$ & Mut & 5 & 132 & Missense & 13074 & Lys $\rightarrow$ Thr & $\mathrm{AAG} \rightarrow \mathrm{ACG}$ & $\mathrm{A} \rightarrow \mathrm{C}$ \\
\hline & LN-d & & $100-1000$ & Mut & 6 & 213 & Nonsense & 13397 & $\mathrm{Arg} \rightarrow \mathrm{STOP}$ & $\mathrm{CGA} \rightarrow \mathrm{TGA}$ & $\mathrm{C} \rightarrow \mathrm{T}$ \\
\hline & $\mathrm{LN}-\mathrm{d}$ & & $100-1000$ & Mut & 8 & 288 & Missense & 14532 & Asn $\rightarrow$ Ser & $\mathrm{AAT} \rightarrow \mathrm{AGT}$ & $\mathrm{A} \rightarrow \mathrm{G}$ \\
\hline \multirow[t]{3}{*}{5} & BM-d & nd & $<100$ & WT & - & - & & - & - & - & - \\
\hline & Tu-d & 75 & $100-1000$ & Mut & 6 & 200 & Missense & 13359 & Asn $\rightarrow$ Ile & $\mathrm{AAT} \rightarrow \mathrm{ATT}$ & $\mathrm{A} \rightarrow \mathrm{T}$ \\
\hline & Asc-d & 85 & Neg & WT & - & - & & - & - & - & - \\
\hline
\end{tabular}

Pat, patient no.; PBL, peripheral blood; Tu, tumour; d, at time of diagnosis; r, relapse; nd, no dates; Mut, mutation; WT, wild-type; Arg, arginine; Cys, cysteine; Lys, lysine; Thr, threonine; amany immature B-cells.

genesis, as well as with haematological cancer. Most p53 mutations found in haematological malignancies are point mutations with rare incidence in B- and T-ALL [5\% in B- and T-ALL $(80,81), 10 \%$ in B-cell NHL (82)] with significant increase (55\%) in AIDS-related NHLs (83), which is a hint of the possible parallel action of mutated p53 and a virus. Farrell et al showed that p53 is frequently mutated in Burkitt's lymphoma cell lines (3). One of the 14 investigated cell lines was EBV transformed, showing p53 mutation in codon 248 of exon 7. A comparable mutation of p53 was found in our investigation in one case. According to the number of mutations found at this position in the UMD p53 database (79), all mutations, except two (codons 141 and 143) that we found in our investigation are located in codons, which harbour $>100$ assigned mutations, and $>1000$ mutations as listed for codons 248 and 273. Mutations in codons 248 and 273 are two of the six 'hot-spots', known to be most frequently associated with cancer (84). In 3 B-ALL patients, we found these mutations in codons 248 and $273(2 \mathrm{x})$, which are additionally described to be classic 'contact mutations'. These mutations remove the essential DNA contact residue Arg-273 (85). The binding capacity of p53 to DNA is reduced about 1000-fold as a result of the 273 mutation, and therefore binding capacity is largely lost (86). The residual binding activity of mutated 273 is too weak for normal transcriptional activity in vivo $(87,88)$. The Arg-248 mutation, found in one patient, is described to affect the DNA contact of p53, resulting in substantially impaired DNA binding in addition to stability loss $(86,89)$. This mutation belongs to the so called 'structural mutations' of the DNA- binding domain of p53, which are known to be essential for the overall architecture of the DNA-binding surface (85). The p53 mutation in codon 175 , found as a homozygous mutation in one B-NHL patient, is known to cause the global denaturation of the p53 gene.

For B-cell lymphoma the transition from $\mathrm{C}$ to $\mathrm{T}$ and $\mathrm{G}$ to $\mathrm{A}$ is an usual event, whereas $\mathrm{G}$ to $\mathrm{T}$ transversions are uncommon (90). In this study, we found these two transitions in 6 out of 20 cases where mutations were detected. We found only $2 \mathrm{G}$ to $\mathrm{T}$ transversions. This is in agreement with the study of Greenblatt et al (90).

The role of p53 in virus-associated tumours, as well as its role in virus replication, have received relatively little attention up to now. Few studies have reflected on this topic, and only in cell culture experiments. The data presented in this study are based on samples derived from patients. SV40 infection leads to the formation of a stable complex between L-TAG and p53. Binding sites for p53 have been mapped to the central core of T-antigen (and E6), and these interactions are impaired by tumour-specific p53 mutations (91). Therefore, in the case of mutated p53 in an SV40-infected cell, there is a double effect that could render the cell to tumorigenesis: SV40 L-TAG binding and inactivating of wild-type p53 and additionally p53 mutation, both hamper the apoptotic way of the cell.

The role of SV40 in the induction of B-cell malignancies, analysed in this study, as well as its possible interaction with p53, wild-type or mutated, are far from being understood. In this study, we show some interesting SV40-p53 constellations. Sixteen out of 19 B-ALL patients showed SV40 positivity at 
the time of diagnosis, while 10 out of these 19 patients showed a p53 mutation as well. After chemotherapy, the mutated p53 signal was lost in all 16 SV40-positive B-ALL patients, whereas they remained positive in respect to SV40, thus indicating that the leukemic clone harbours the p53 mutation. In contrast, SV40 positivity persisted, which may be interpreted as follows: Normal BM cells of these patients also harbour SV40. Whether individual leukemic cells are SV40-positive is not clear and cannot be answered until SV40 and p53 are analysed on a single cell basis.

The simultaneous existence of SV40 and mutated p53 is presumably more likely to occur in LNs, as demonstrated in this study (Table IV, patients 2 and 4). Nevertheless, the high SV40 copy number combined with mutated p53 in LNs, containing a high blast percentage, maybe a hint, that SV40 and mutated p53 act together in the same cell. However, the results obtained from the tissue samples of B-NHL patient 3 are not easy to explain. In B-NHL patient samples where p53 mutation co-exists with SV40, we detected a high copy number of SV40 (1000 copies of SV40 per $500 \mathrm{ng}$ DNA). This could be demonstrated for LNs as well as for Ascs at the time of diagnosis. Moreover, the LNs of patients 1 and 4 (Table IV) showed 2 (patient 1) and 3 (patient 4) different p53 mutations. In 2 SV40-positive B-NHL patients, p53 mutation was even homozygous at the time of diagnosis. In the case of the p53 wild-type constellation, the SV40 copy number was very low ( $<100$ copies per 500 ng DNA) or negative.

In the case of p53 mutation one can assume that at least one mutated p53 allele exists per leukemic cell and that this is not congruent with the calculated SV40 copy number (one SV40 copy per 10 or 100 cells). In this study, we conclude that in comparison to the p53 mutation number, the SV40 copy number is low. With our approach of a simultaneous existence a cooperation of SV40 and p53 in leukemic cells cannot be proven. From our data it can be derived that normal BM (BM in remission in this study) is a reservoir of SV40 which nevertheless could be involved in the induction of B-NHL and B-ALL as well as p53 mutations. But this needs more investigation. Without more data regarding the individual leukaemia/ lymphoma cell on a single cell basis, concerning SV40 and p53 mutation, one can only presume about the cooperative transformation mechanism of these two.

A bystander effect from SV40-infected BM cells contributing to an oncogenic milieu, resulting in B-ALL induction, and p53 mutation, is possible. Therefore, SV40 infection possibly increases the oncogenic milieu of the cell, at least playing a role in controlling gene function and modulation of mutability in the case of p53 mutation. Infection with the oncogenic virus, SV40, possibly creates a local cancer milieu in the infected cell for alteration of genes e.g. the p53 gene. Cooperative oncogenic events, leading to a special local cancer milieu of the cell, have been previously described for other viruses playing a role in cancer development, e.g. for papillomaviruses (cervical neoplasia) (92) or HIV (plasma cell tumour) (93). A milieu effect was also discussed in the pathogenesis of other malignant diseases, such as lung cancer (94) and thyroid tumorigenesis (95).

A mechanism utilising the enzyme activated cytidine deaminase is an important player in the natural immunity against viral infections, and could lead to transforming point mutations in cellular genes, e.g. the p53 gene. The high discrepancies of SV40 and p53 copy numbers could suggest a 'hit and run' mechanism where the initial presence of SV40 was lost during the transformation mechanism. Virus-associated tumours often display point mutations in p53 (91), as was also demonstrated in this study on childhood lymphoproliferative disorders. Therefore, the question is: Does p53 mutation represent a separate pathway to tumour development, or does viral antagonism predispose to p53 mutation?

Neil et al discuss, that in viral infections it could be necessary to suppress apoptosis caused by forced entry into the $S$ phase (91). However, other viral proteins could achieve this effect: Adenovirus E1B 19K suppresses most types of apoptosis. Perhaps p53 has other functions that DNA viruses, such as SV40, need to eliminate. This has to be investigated thoroughly in further investigations. In the case of B-NHL/B-ALL, as shown in this study, it is possible, that mutated p53 and SV40 can act together to render these cells more sensitive to leukemia. Carbone et al showed that p53 is not only a passive inactive partner of SV40 L-TAG, but can promote malignant cell growth. They demonstrated that the p53 L-TAG complex binds to the IGF-I gene and therefore stimulates the activation of the IGF-I pathway (96). This demonstrates that the dogma, that SV40 L-TAG inactivates p53 function completely, has to be re-assessed.

The role of p53 in virus-associated tumours remains unclear. While in some tumours, such as cervical carcinoma, mutations of p53 occur preferentially in tumours without HPV infection (97), we demonstrated in this study that p53 mutations are frequent in SV40-infected B-cell lymphomas as well as in B-NHLs. To the best of our knowledge, this current report is the first of its kind, investigating the prevalence of SV40 in patients with lymphomas in Germany and the most extensive study correlating the p53 mutation rate with SV40 prevalence in childhood lymphoproliferative disorders. In the case of SV40, our investigation indicates a putative viral cause for B-NHL/B-ALL development as well as in other childhood lymphoproliferative disorders, such as T- and BCP-ALL. In all tested LNs of B-NHL patients we found one or more p53 mutations, among them one homozygous and one nonsense mutation. All of these LNs were SV40-positive with 100-1000 SV40 copies in $500 \mathrm{ng}$ DNA. From one patient we additionally analysed BM with wild-type p53, showing < 100 SV40 copies per 500 ng DNA. Due to the high content of vital tumour cells in all LNs (71-98\%) and the high copy number of SV40 in one to 3 different p53 mutations, we can conclude, that SV40 and p53 mutation occur in the same cell, promoting lymphoma development. Therefore, SV40 infection and p53 mutation could be seen as cooperative oncogenic events.

In conclusion, SV40 should be added to the list of factors playing a role in the pathogenesis of B-cell lymphoma, acting together with mutated p53 in the multistep tumorigenesis of lymphoproliferative disorders.

\section{Acknowledgements}

We thank all the members of the Cooperative ALL-Study (COALL) group in Germany for providing leukaemia samples. The SV80 and COS-7 cell lines were kindly provided by Professor Wolfgang Deppert (Heinrich-Pette-Institut, 
Hamburg, Germany). Real-time primers were designed by Olfert Landt (TibMol Biol, Berlin, Germany). We also thank the Fördergemeinschaft Kinderkrebszentrum Hamburg e.V. as well as Dr Rainer Maas (Hamburg) for financial support.

\section{References}

1. Jarret R: Viruses and lymphoma/leukaemia. J Pathol 208: 176-186, 2006

2. Coles A, Marfella C, Imbalzano A, et al: P37Ing1b regulates $\mathrm{B}$-cell proliferation and cooperates with $\mathrm{p} 53$ to suppress diffuse large B-cell lymphomagenesis. Cancer Res 68: 8705-8714, 2008.

3. Farrell P, Allan G, Shanahan F, Vousden K and Crook T: p53 is frequently mutated in Burkitt's lymphoma cell lines. EMBO J 10: 2879-2887, 1991.

4. Smardova J, Grochova D, Fabian P, et al: An unusual p53 mutation detected in Burkitt's lymphoma: 30 bp duplication. Oncol Rep 20: 773-778, 2008.

5. Hosny G, Farahat N and Hainaut P: TP53 mutations in circulating free DNA from Egyptian patients with non-Hodgkin's lymphoma. Cancer Lett 275: 234-239, 2009.

6. Cerroni L, Zochling N, Putz B and Kerl H: Infection by Borrelia burgdorferi and cutaneous B-cell lymphoma. J Cutan Pathol 24 457-461, 1997.

7. Kutting B, Bonsmann G, Metze D, Luger TA and Cerroni L: Borrelia burgdorferi-associated primary cutaneous B cell lymphoma: Complete clearing of skin lesions after antibiotic pulse therapy or intralesional injection of interferon alfa-2a. J Am Acad Dermatol 36: 311-314, 1997.

8. Niedobitek G, Meru N and Delecluse H: Epstein-Barr virus infection and human malignancies. Int J Exp Pathol 82: 149-170, 2001.

9. Butel JS: Viral carcinogenesis: Revelation of molecular mechanisms and etiology of human disease. Carcinogenesis 21 : 405-426, 2000.

10. Kelly G and Rickinson A: Burkitt lymphoma: Revisiting the pathogenesis of a virus-associated malignancy. Hematology Am Soc Hematol Educ Program 277-284, 2007.

11. Du M, Diss T, Liu H, Ye H, Hamoudi R and Cabecadas J: KSHV- and EBV-associated germinotropic lymphoproliferative dicorder. Blood 100: 3415-3418, 2002.

12. Levy LS and Bost KL: Mechanisms that contribute to the development of lymphoid malignancies: Roles for genetic alterations and cytokine production. Crit Rev Immunol 16: 31-57, 1996.

13. Moller MB, Nielsen O and Pedersen NT: Frequent alteration of MDM2 and p53 in the molecular progression of recurring non-Hodgkin's lymphoma. Histopathology 41: 322-330, 2002.

14. Raphael M, Borisch B and Jaffe E: Lymphomas associated with infection by the human immune deficiency virus (HIV). In: World Health Organisation Classification of Tumours: Pathology and Genetics of Tumours of Hematopoietic and Lymphoid Tissues. Jaffe ES, Harris NL, Stein H and Vardiman JW (eds) IARC, Lyon, pp260-263, 2001.

15. Mele A, Pulsoni A, Bianco E, Musto P, Szklo A and Sanpaolo M: Hepatitis $\mathrm{C}$ virus and B-cell non-Hodgkin lymphomas: An Italian multicenter case-control study. Blood 102: 996-999, 2003.

16. Engels E, Chatterjee N, Cerhan J, Davis S, Cozen W and Severson R: Hepatitis C virus infection and non-Hodgkin lymphoma: Results of the NCI-SEER multi-center case-control study. Int J Cancer 111: 76-80, 2004.

17. Sangar D, Pipkin P, Wood D and Minor P: Examination of poliovirus vaccine preparations for SV40 sequences. Biologicals 27: 1-10, 1999.

18. Shah K and Nathanson N: Human exposure to SV40: review and comment. Am J Epidemiol 103: 1-12, 1976.

19. Sweet B and Hillemann M: The vacuolating virus, S.V.40. Proc Soc Exp Biol Med 105: 420-427, 1960.

20. Shein HM, Enders JF and Levinthal JD: Transformation induced by simian virus 40 in human renal cell cultures. II. Cell-virus relationships. Proc Natl Acad Sci USA 48: 1350-1357, 1962.

21. Ahuja D, Saenz-Robles M and Pipas J: SV40 large T antigen multiple cellular pathways to elicit cellular transformation. Oncogene 24: 7729-7745, 2005.

22. Diamandopoulos GT: Leukemia, lymphoma, and osteosarcoma induced in the Syrian golden hamster by simian virus 40 . Science 176: 173-175, 1972.
23. Shivapurkar N, Harada K, Reddy J, et al: Presence of simian virus 40 DNA sequences in human lymphomas. Lancet 359: 651-852, 2002.

24. Vilchez RA and Butel JS: Simian virus 40 and its association with human lymphomas. Curr Oncol Rep 5: 372-379, 2003.

25. de Sanjose S, Shah KV, Domingo-Domenech E, et al: Lack of serological evidence for an association between simian virus 40 and lymphoma. Int J Cancer 104: 522-524, 2003.

26. Meneses A, Lopez-Terrada D, Zanwar P, et al: Lymphoproliferative disorders in Costa Rica and simian virus 40. Haematologica 90: 1635-1642, 2005.

27. Butel JS, Vilchez RA, Jorgensen JL and Kozinetz CA: Association between SV40 and non-Hodgkin's lymphoma. Leuk Lymphoma 44 (Suppl 3): 33-39, 2003.

28. David H, Mendoza S, Konishi T and Miller CW: Simian virus 40 is present in human lymphomas and normal blood. Cancer Lett 162: 57-64, 2001.

29. MacKenzie J, Wilson K, Perry J, Gallagher A and Jarrett R: Association between simian virus 40 DNA and lymphoma in the United Kingdom. J Natl Cancer Inst 95: 1001-1003, 2003.

30. Vilchez RA and Butel JS: Polyomavirus SV40 infection and lymphomas in Spain. Int J Cancer 107: 505-508, 2003.

31. Vilchez RA and Butel JS: Simian virus 40 infection in lymphoproliferative disorders. Lancet 361: 1565-1566, 2003.

32. Martini F, Dolcetti R, Gloghini A, et al: Simian-virus-40 footprints in human lymphoproliferative disorders of HIV- and $\mathrm{HIV}^{+}$patients. Int J Cancer 78: 669-674, 1998.

33. Rizzo P, Carbone M, Fisher SG, et al: Simian virus 40 is present in most United States human mesotheliomas, but it is rarely present in non-Hodgkin's lymphoma. Chest 116: S0470-S473, 1999.

34. Vilchez RA, Madden CR, Kozinetz CA, et al: Association between simian virus 40 and non-Hodgkin lymphoma. Lancet 359: 817-823, 2002.

35. Yazdi A, Puchta U, Flaig M and Sander C: Lack of evidence for the presence of Simian virus 40 DNA in cutaneous lymphomas. J Invest Dermatol 121: 212-213, 2003.

36. Capello D, Rossi D, Gaudino G, Carbone A and Gaidano G: Simian virus 40 infection in lymphoproliferative disorders. Lancet 361: 88-89, 2003.

37. Nakatsuka S, Liu A, Dong Z, et al: Simian virus 40 sequences in malignant lymphomas in Japan. Cancer Res. 63: 7606-7608, 2003.

38. Jasani B, Cristaudo A and Emri S: Association of SV40 with human tumours. Semin Cancer Biol 11: 49-61, 2001.

39. Brousset P, de Araujo V and Gascoyne R: Immunohistochemical investigation of SV40 large T antigen in Hodgkin and non-Hodgkin's lymphoma. Int J Cancer 112: 5333-5535, 2004.

40. Vilchez RA, Lopez-Terrada D, Middleton JR, et al: Simian virus 40 tumor antigen expression and immunophenotypic profile of aids-related non-Hodgkin's lymphoma. Virology 342: 38-46, 2005.

41. Heinsohn S, Golta S, Kabisch H and zur Stadt U: Standardized detection of Simian virus 40 by real-time quantitative polymerase chain reaction in pediatric malignancies. Haematologica 90: 94-99, 2005.

42. McNees AL, White ZS, Zanwar P, Vilchez RA and Butel JS: Specific and quantitative detection of human polyomaviruses BKV, JCV, and SV40 by real time PCR. J Clin Virol 34: 52-62, 2005.

43. Lane $\mathrm{D}$ and Crawford $\mathrm{L}: \mathrm{T}$ antigen is bound to a host protein in SV40-transformed cells. Nature 278: 261-263, 1979.

44. Linzer D and Levine A: Characterization of a $54 \mathrm{~K}$ dalton cellular SV40 tumor antigen present in SV40-transformed cells and uninfected embryonal carcinoma cells. Cell 17: 43-52, 1979.

45. Levine A, Momand J and Finlay C: The p53 tumour suppressor gene. Nature 351: 453-456, 1991.

46. Cowell J: The nuclear oncoproteins: RB and p53. Sem Cancer Biol 1: 437-446, 1990

47. Lane D: P53, guardian of the genome. Nature 358: 15-16, 1992.

48. Soussi T: Focus on the p53 gene and cancer: advances in TP53 mutation research. Hum Mutat 21: 173-175, 2003.

49. Spandidos DA, Liloglou T and Field J: Prognostic significance of oncogenes and tumor suppressor genes in human malignancy. Stem Cells 11: 194-198, 1993.

50. Scholz RB, Kabisch H, Weber B, Roser K, Delling G and Winkler K: Studies of the RB1 gene and the p53 gene in human osteosarcomas. Pediatr Hematol Oncol 9: 125-137, 1992. 
51. Scholz RB, Milde-Langosch K, Jung R, et al: Rapid screening for Tp53 mutations by temperature gradient gel electrophoresis: A comparison with SSCP analysis. Hum Mol Genet 2: 2155-2158, 1993.

52. Scholz RB, Christiansen H, Kabisch H and Winkler K: Molecular markers in the evaluation of bone neoplasms. In: Pathology of Bone and Joint Neoplasms. Helliwell TR (ed). W.B. Saunders, Philadelphia, PA, pp79-105, 1999.

53. Smock K, Nelson M, Tripp S, et al: Characterization of childhood precursor T-lymphoblastic lymphoma by immunophenotyping and fluorescent in situ hybridization: a report from the Children's Oncology Group. Pediatr Blood Cancer 51: 489-494, 2008.

54. Nakamura M, Shimada K, Ishida E, et al: Molecular pathogenesis of peadiatric astrocytic tumors. Neuro Oncol 9: 113-123, 2007.

55. Peller S and Rotter V: Tp53 in hematological cancer: Low incidence of mutations with significant clinical relevance. Hum Mutat 21: 277-284, 2003.

56. Preudhomme $\mathrm{C}$ and Fenaux P: The clinical significance of mutations of the p53 tumor suppressor gene in heamatological malignancies. Br J Haematol 98: 502-511, 1997.

57. Krug U, Ganser A and Koeffler H: Tumor suppressor genes in normal and malignant hematopoiesis. Oncogene 21: 3475-3495, 2002.

58. Zainuddin N, Berglund M, Wanders A, et al: Tp53 mutations predict for poor survival in de novo diffuse large B-cel lymphoma of germinal center subtype. Leuk Res 33: 60-66, 2009 .

59. O'Shea D, O'Riain C, Taylor C, et al: The presence of TP53 mutations at diagnosis of follicular lymphoma identifies a high-risk group of patients with shortened time to disease progression and poorer overall survival. Blood 112: 3126-3129, 2008.

60. Young K, Leroy K, Moller M, et al: Structural profiles of TP53 gene mutations predict clinical outcome in diffuse large B-cel lymphoma: An international collaborative study. Blood 112: 3088-3098, 2008.

61. Sherr C: Cancer cell cycles. Science 274: 1672-1677, 1996.

62. Vogelstein B, Lane D and Levine A: Surfing the p53 network. Nature 408: 307-310, 2000.

63. Montenarh M, Kohler M and Henning R: Complex formation of simian virus 40 large $\mathrm{T}$ antigen with cellular protein $\mathrm{p53}$. J Viro 60: 761-764, 1986.

64. McCormick F and Wood D: The role of $\mathrm{p} 53$ in virally associated tumors. Trends Microbiol 5: 181-182, 1997.

65. Levine A: The p53 tumor suppressor gene and gene product. Princess Takamatsu Symp 20: 221-230, 1989.

66. Hoppe-Seyler F and Butz K: Molecular mechanisms of virusinduced carcinogenesis: the interaction of viral factors with cellular tumor suppressor proteins. J Mol Med 73: 529-538, 1995.

67. Schreier AA and Gruber J: Viral T-antigen interactions with cellular proto-oncogene and anti-oncogene products. J Nat Cancer Inst 82: 354-360, 1990

68. Hinds P, Finlay C, Quartin R, et al: Mutant p53 clones from human colon carcinoma cooperate with ras in transforming primary rat cells: a comparison of the 'hot spot' mutant phenotypes. Cell Growth Differ 1: 571-580, 1990.

69. Levine A: The common mechanisms of tranformation by small DNA tumor viruses: The inactivation of tumor suppressor gene products: p53. Virology 384: 285-293, 2009.

70. Amara K, Trimeche M, Ziadi S, et al: Presence of simian virus 40 in diffuse large B-cell lymphomas in Tunisia correlates with germinal center B-cell immunophenotype, $t(14 ; 18)$ translocation, and p53 accumulation. Mod Pathol 21: 282-296, 2008.

71. Lednicky JA and Butel JS: Consideration of PCR methods for the detection of SV40 in tissue and DNA specimens. Dev Biol Stand 94: 155-164, 1998.

72. Strickler HD: A multicenter evaluation of assays for detection of SV40 DNA and results in masked mesothelioma specimens. Cancer Epidemiol Biomarkers Prev 10: 523-532, 2001.

73. Rizzo P, Di Resta I, Powers A, et al: The detection of simian virus 40 in human tumors by polymerase chain reaction. Monaldi Arch Chest Dis 53: 202-210, 1998.

74. Heinsohn S, Scholz RB, Weber B, et al: SV40 sequences in human osteosarcoma of German origin. Anticancer Res 20 4539-4545, 2000.
75. Caron-de-Fromentel C and Soussi T: TP53 tumor suppressor gene: a model for investigating human mutagenesis. Genes Chromosomes Cancer 4: 1-15, 1992.

76. Hollstein M, Sidransky D, Vogelstein B and Harris C: p53 mutations in human cancers. Science 253: 49-53, 1991.

77. Weyrer K, Feichtinger H, Haun M, et al: p53, Ki-ras, and DNA ploidy in human pancreatic ductal adenocarcinomas. Lab Invest 74: 279-289, 1996

78. Sturm I, Köhne C, Wolff G, et al: Analysis of the p53/BAX pathway in colorectal cancer: low BAX is a negative prognostic factor in patients with resected liver metastasis. J Clin Oncol 17: 1364-1374, 1999

79. http://p53.free.fr/Database/p53:

80. Kawamura M, Ohnishi $\mathrm{H}$, Guo S, et al: Alterations of the p53, p21, p16, p15 and RAS genesin childhood T-cell acute lymphoblastic leukemia. Leukemia 23: 115-126, 1999.

81. Zhou M, Gu L, Yeager A and Findley H: Sensitivity to Fas-mediated apoptosis in peadiatric acute lymphoblastic leukemia is associated with a mutant p53 phenotype and absence of Bcl-2 expression. Leukemia 12: 1756-1763, 1998.

82. Stokke T, Galteland E, Holte H, et al: Oncogenic aberrations in the $\mathrm{p} 53$ pathway are associated with a high $\mathrm{S}$ phase fraction and poor patient survival in B-cell Non-Hodgkin's lymphoma. Int J Cancer 89: 313-324, 2000

83. Martin A, Flaman J, Frebourg T, et al: Functional analysis of the p53 protein in AIDS-rtalated non-Hodgkin's lymphomas and polymorphic lymphoproliferations. Br J Heamatol 101: 311-317, 1998.

84. Hainaut $\mathrm{P}$ and Hollstein M: p53 and human cancer: the first ten thousand mutations. Adv Cancer Res 77: 81-137, 2000.

85. Joerger A and Fersht A: Structural biology of the tumor suppressor p53. Annu Rev Biochem 77: 557-582, 2008.

86. Ang H, Joerger A, Mayer S and Fersht A: Effects of common cancer mutations on stability and DNA binding of full-length p53 compared with isolated core domains. J Biol Chem 281: 21934-21941, 2006.

87. Kato S, Han S-Y, Liu W, et al: Understanding the functionstructure and function-mutation relationship of p53 tumor suppressor protein by high-resolution missense mutation analysis. Proc Natl Acad Sci USA 100: 8424-8429, 2003.

88. Dearth L, Qian H, Wang T, et al: Inactive full-length p53 mutants lacking dominant wild-type p53 inhibition highlight loss of heterozygosity as an important aspect of p53 status in human cancers. Cancerogenesis 28: 289-298, 2007.

89. Joerger A, Ang H, Veprintsev D, Blair C and Fersht A: Structures of p53 cancer mutants and mechanism of rescue by second-site suppressor mutations. J Biol Chem 280: 16030-16037, 2005

90. Greenblatt M, Bennet W and Hollstein M: Mutations in the p53 tumor suppressor gene: clues to cancer etiology and molecular pathogenesis. Cancer Res 54: 4855-4878, 1994

91. Neil J, Cameron E and Baxter E: p53 and tumour viruses: Catching the guardian off-guard. Trends Microbiol 5: 115-120, 1997.

92. Sheu B, Chang W, Lin H, Chow S and Huang S: Immune concept of human papillomaviruses and related antigens in local cancer milieu of human cervical neoplasia. J Obstet Gynaecol Res 33: 103-113, 2007.

93. Salarieh A, Rao C, Gottesmann S, Alagha O, Todor R and Axiotis C: Plasma cell tumors in HIV-positive patients: Report of a case and review of the literature. Leuk Lymphoma 46: 1067-1074, 2005

94. Manenti G, Trincucci G, Pettinicchio A, Amendola E, Scarfo M and Dragani T: Cis-acting genomic elements of the Pas1 locus control Kras mutability in lung cancer. Oncogene 27: 5753-5758, 2008.

95. Reddi H, McIver B, Grebe $\mathrm{S}$ and Eberhardt N: The paired box-8/ peroxisome proliferator-activated receptor-y oncogene in thyroid tumorigenesis. Endocrinology 148: 932-935, 2007.

96. Carbone M, Pannuti A, Zhang L, Testa J and Bochetta M: A novel mechanism of late gene silencing drives SV40 transformation of human mesothelia cells. Cancer Res 68: 9488-9496, 2008.

97. Paquette R, Lee Y, Wilczynski S, et al: Mutations of p53 and human papillomavirus infection in cervical carcinoma. Cancer 72: 1272-1280, 1993. 